The real find of the Fair Ground Excavations, however, was made just outside the north wall of the compound. Two heads of mountain sheep, cut from sandstone, proved to be of outstanding interest (Figure 5). These heads are carved from what seems to be Yavapai sandstone, a material peculiar to this immediate area; this fact would indicate that the heads were made in the immediate vicinity, perhaps on the site of the old habitation within the walls of the compound.

The soil surrounding the compound walls where the rams, heads were unearthed, and within their confines, was very black, apparently containing burned organic matter. Each figure was discolored over an area extending from the base to within eight inches of the top, offering the appearance of having been through fire. Outside this area, which was the portion buried beneath the floor or soil level, the heads were of the natural sandstone color.

The horizontal distance through each head from the outside of one horn to the outside of the other is approximately ten inches. The greatest vertical length measurement is fifteen inches in one figure and eighteen in the other.

These mountain sheep heads, curious specimens of the carving of early inhabitants of the Prescott region, are now on display at the Smoki Public Museum in Prescott, Arizona.

Malcolm B. Cummings

Clarkdale, Arizona

\title{
Credit to Previous Investigators
}

In the April number of American Antiquity, there is an excellent article by Dr. E. E. Tyzzer on bone points from shell heaps in Maine, which I read with great interest. I have no desire to criticise Dr. Tyzzer's excellent work, yet I think it is proper to express regret that there is no mention in his bibliography of the many seasons which I spent in the exploration of Maine shell heaps. In our book, Archaeology of Maine, I devoted fifty-four pages to this subject, illustrating many of the bone points described by Dr. Tyzzer in his article. Those who read his article will naturally conclude that very little work has been done along the Maine coast except by the gentlemen whom he has named. There is a large collection of these points in the Andover Museum. That some of them were used as tips to arrows I do not doubt; others, however, we believe were fish-hooks. They could be fastened as was done on the Northwest Coast, and used effectively for the taking of halibut, cod and other large fish. One of my men made experiments in line with this interpretation many years ago, and was able to catch a few fish with these points.

I trust readers will pardon me if I state that much of my life has been spent in studying chipped objects and their use. I firmly believe that Indians favored, for hunting, a broad stone or bone point rather than slender bone points. The Indian was primarily interested in killing large game, and he knew that a broad or rather heavy arrow point of stone made a larger wound, thus 
causing considerable loss of blood and weakening the animal. Furthermore, Indians did much of their hunting in winter. By means of snow shoes, they approached deer or moose, particularly in deep snow, and were able to use, at close quarters, spears or lances. In addition to spears, they carried their bows and arrows.

I would suggest that our present day writers or investigators, while presenting observations in more detail than appeared in reports published years ago, be careful to accord credit to previous explorers. This would in no wise detract from their able and valuable dissertations.

I might remark in passing that in fields other than New England there have been-probably inadvertently-omissions of reference to previous investigators work and reports.

This summer, in Maine, I met a gentleman who has hunted big game here, in Africa, and elsewhere. I also talked with one or two persons who had served with us on previous expeditions and are familiar with game and local conditions in this state. We discussed the use of short worked bones as arrow points. They approached the subject from the viewpoint of the hunter and practical woodsman. The fact that these bone points are confined to shell heaps along our coast from eastern New Brunswick to Portland, Maine, is very significant. They are not found at sites in the great hunting regions of central Maine, Penobscot, Kennebec, and other valleys. Were they used primarily for the killing of game we would find them in village sites, ash pits, etc. Yet they do not occur beyond the shore line where are clam flats and the larger salt water fish.

Projectile points of stone are found in great numbers in the interior, up rivers, and also occur in many shell heaps.

With reference to the killing of big game by primitive man, one's mind reverts to an experiment performed by us in a slaughter-house at Methuen, Massachusetts. I am sorry that these observations did not receive more publicity. They were based on the contention of a practical hunter to the effect that the palaeolithic "fist axe," of Chellean type, could not be used effectively against large game, as borne out by his and our experiments on living and dead animals.

The parallel between this and the use of slender projectile points is not exact, yet the principle is practically the same.

I have no desire to criticize our able scholars who are engaged in laboratory experiments, but I do believe we should approach this general subject from the point of view of the Indian hunter. His "outfit" varied according to necessity. The bone points in question are fashioned from the bones of large animals rather than those of birds, and seldom of the seal. However, while the bones so utilized are in situ at the kitchen middens, the points themselves are absent back from the coast where the large animals were hunted.

Warren King Moorehead, Director

Department of Archaeology

Phillips Academy, Andover, Massachusetts 